Article

\title{
Interplay of Nutrients, Temperature, and Competition of Native and Alien Cyanobacteria Species Growth and Cyanotoxin Production in Temperate Lakes
}

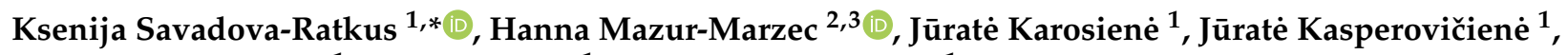 \\ Ričardas Paškauskas ${ }^{1}$, Irma Vitonyte ${ }^{1}$ and Judita Koreivienè ${ }^{1, *}$ \\ 1 Department of Algology and Microbial Ecology, Nature Research Centre, Akademijos Str. 2, \\ LT-08412 Vilnius, Lithuania; jurate.karosiene@gamtc.lt (J.K.); jurate.kasperoviciene@gamtc.lt (J.K.); \\ ricardas.paskauskas@gamtc.lt (R.P.); irma.vitonyte@gmail.com (I.V.) \\ 2 Division of Marine Biotechnology, Institute of Oceanography, University of Gdańsk, al. Marszałka \\ Piłsudskiego 46, PL-81-378 Gdynia, Poland; hanna.mazur-marzec@ug.edu.pl \\ 3 Institute of Oceanology, Polish Academy of Sciences, Powstańców Warszawy 55, PL-81-712 Sopot, Poland \\ * Correspondence: ksenija.savadova.ratkus@gmail.com (K.S.-R.); judita.koreiviene@gamtc.lt (J.K.)
}

Citation: Savadova-Ratkus, K.; Mazur-Marzec, H.; Karosienè, J.; Kasperovičienė, J.; Paškauskas, R.; Vitonytė, I.; Koreivienè, J. Interplay of Nutrients, Temperature, and Competition of Native and Alien Cyanobacteria Species Growth and Cyanotoxin Production in Temperate Lakes. Toxins 2021, 13, 23. https://doi.org/10.3390/toxins 13010023

Received: 2 December 2020 Accepted: 29 December 2020 Published: 1 January 2021

Publisher's Note: MDPI stays neutral with regard to jurisdictional clai$\mathrm{ms}$ in published maps and institutional affiliations.

Copyright: $\odot 2021$ by the authors. Licensee MDPI, Basel, Switzerland. This article is an open access article distributed under the terms and conditions of the Creative Commons Attribution (CC BY) license (https:// creativecommons.org/licenses/by/ $4.0 /)$.

\begin{abstract}
Global warming and eutrophication contribute to formation of HABs and distribution of alien cyanobacteria northward. The current study assessed how alien to Europe Sphaerospermopsis aphanizomenoides and Chrysosporum bergii will co-occur with dominant native Planktothrix agardhii and Aphanizomenon gracile species under changing conditions in temperate freshwaters. The experiments were carried out to examine the effect of nutrients and temperature on the growth rate of cyanobacteria, production of cyanotoxins, and interspecies competition. The highest growth rate was determined for A. gracile $\left(0.43 \mathrm{day}^{-1}\right)$ and S. aphanizomenoides $\left(0.40 \mathrm{day}^{-1}\right)$ strains at all the tested nutrient concentrations (IP and IN were significant factors). S. aphanizomenoides adapted to the wide range of nutrient concentrations and temperature due to high species ecological plasticity; however, A. gracile was able to suppress its dominance under changing conditions. Regularity between tested variables and STX concentration in A. gracile was not found, but IP concentration negatively correlated with the amount of dmMC-RR and other non-ribosomal peptides (NRPs) in P. agardhii strains. The relative concentration of NRPs in nontoxic P. agardhii strain was up to 3-fold higher than in MC-producing strain. Our study indicated that nutrients, temperature, and species had significant effects on interspecies competition. A. gracile had a negative effect on biomass of both alien species and P. agardhii.
\end{abstract}

Keywords: Aphanizomenon; Chrysosporum; Planktothrix; Sphaerospermopsis; microcystins; saxitoxin; non-ribosomal peptides; bloom-forming cyanobacteria; Europe; freshwater shallow lakes

Key Contribution: This article examines the competitive potential of native and alien to Europe cyanobacteria species under changing environmental conditions that may predetermine production of cyanometabolites and their structure in freshwaters. Native Aphanizomenon gracile aggravates alien (Chrysosporum bergii, Sphaerospermopsis aphanizomenoides) species establishment, while MCs producing and non-producing Plaktothrix agardhii might contribute to cumulative negative effect on aquatic organisms due to the production of other bioactive NRPs.

\section{Introduction}

Global warming and anthropogenic eutrophication simultaneously contribute to formation of harmful algal blooms (HABs) worldwide, which are the biggest threat to freshwater ecosystems. Cyanobacteria may comprise over $70 \%$ of the total phytoplankton biomass in eutrophic lakes [1] at biomass reaching a high alert level $\left(>12.5 \mathrm{mg} \mathrm{L}^{-1}\right)$, according to the World Health Organization [2] recommendations for bathing waters. Toxicity of 
the cyanobacteria bloom depends on the structure of cyanobacterial community and the biomass of toxin-producing strains [3,4]. Among cyanotoxins, hepatotoxic microcystins (MCs) are the most common in European water bodies [5,6]; less frequently, the occurrence of neurotoxins and other bioactive metabolites of cyanobacteria has been reported from freshwaters of the continent. The results of the European Multi Lake Survey (EMLS) revealed MCs occurrence in 93\%, while cylindrospermopsin (CYN) and anatoxin (ATX) were detected in $39 \%$ of the 137 EMLS lakes [6].

Anthropogenic eutrophication increases bioavailable nitrogen $(\mathrm{N})$ and phosphorus $(\mathrm{P})$ concentrations in freshwaters; however, it is still debated which of these two elements is more important for the HABs formation. Some authors refer to phosphorus as the main limiting element for primary production and magnitude of the bloom [7], while the others have shown that both P and N can control the blooms' occurrence and intensity [8-10]. According to Klausmeier et al. [11], the cyanobacteria response to N:P is species-specific; therefore, the ratio might be important for species composition in the water body. Bloom-forming cyanobacteria (Dolichospermum, Aphanizomenon, and Cylindrospermopsis/Raphidiopsis) are able to fix $\mathrm{N}_{2}$ [12] and have strong competitive capabilities under nitrogen-limiting conditions [13,14]. However, Dolman et al. [15] revealed that various $\mathrm{N}_{2}$ fixing species have different preferences regarding $\mathrm{N}$ vs. P concentrations. Non-diazotrophic cyanobacteria such as Microcystis and Planktothrix dominate in the shallow eutrophic lakes under Nreplete conditions $[16,17]$ and evolved the capability to store the nutrients in the cells under limiting conditions $[18,19]$. Current understanding is insufficient to determine how concentrations of nutrients and their ratio challenge individual species. Therefore, it is crucial to assess how changing nutrients will result in "winners" and "losers" in phytoplankton assemblages [20].

In temperate lakes, competition for the main resources (e.g., nutrients, light) determine the complexes of dominant and co-occurring native cyanobacteria species [21,22]. However, due to climate change, the recent spread of alien cyanobacteria has put a great risk such that new competitive species may break the steady balance of native cyanobacteria dynamics and structure. The successful spread of Chrysosporum bergii and Sphaerospermopsis aphanizomenoides alien species in European temperate regions such as Poland [23,24], the Czech Republic [25], and Germany [26] in recent years has already been recognized. Lithuania is known as one of the most northern points for those cyanobacteria, and both species were detected in the shallow eutrophic lakes at low concentrations [27-30]. Warming is referred to as a favorable factor for the recent spread of invasive species to northern Europe [31]. However, it has not been fully disclosed how nutrient enrichment and competition with native species could affect their establishment in new areas.

The current paper addressed the potential risk of alien species invading temperate freshwaters. The effect of nutrients and temperature on the strains of native Planktothrix agardhii, Aphanizomenon gracile and alien to Europe Chrysosporum bergii and Sphaerospermopsis aphanizomenoides cyanobacteria and their competition are highlighted. The aim of the study was to disclose proliferation, cyanotoxins synthesis, and interspecies competition of dominant native and alien cyanobacteria in temperate lakes under increasing temperature and eutrophication conditions.

\section{Results}

\subsection{Experiment I: Effect of Nutrients on Native and Alien Cyanobacteria}

\subsubsection{Effect of Nutrients on the Growth Rate of Cyanobacteria Strains}

The General linear model (GLM) showed that nutrient concentrations and N:P atomic ratio significantly affected the growth rate of all tested cyanobacteria strains (Table 1). However, the response was species- and strain-specific. The highest growth rates were found for strains of Aphanizomenon gracile $\left(0.43 \pm 0.08\right.$ day $\left.^{-1}\right)$ and Sphaerospermopsis aphanizomenoides $\left(0.40 \pm 0.12 \mathrm{day}^{-1}\right)$ at all of the tested nutrient concentrations, and especially at more eutrophic and hypertrophic conditions (Figure 1). IP and IN impacted on both species growth rate, whereas for the $A$. gracile N:P ratio was also significant (Table 1 ). 
The lowest growth rate among the tested cyanobacteria was characteristic for Planktothrix agardhii strains $\left(0.14 \pm 0.25\right.$ day $\left.^{-1}\right)$ and showed the biggest differences in growth under tested treatments. The maximum growth rate of $P$. agardhii was reached at the highest IP concentrations ( $\left.0.51 \mathrm{mg} \mathrm{P} \mathrm{L}^{-1}\right)$ and at $\mathrm{N}: \mathrm{P}$ ratio of $30: 1$, whereas low IP concentrations and $\mathrm{N}: \mathrm{P}$ atomic ratio inhibited the cyanobacterium growth. The GML analysis revealed that the IP and IN concentrations, and N:P ratio were important for the growth of both strains of $P$. agardhii. The growth rate $\left(0.18 \pm 0.11\right.$ day $\left.^{-1}\right)$ of Chrysosporum bergii was strain-specific and considerably differed under tested nutrient concentrations. The tested variables showed no significant impact on C. bergii growth rate (Table 1).

Table 1. General linear model (GLM) results for factors' impact on the response variable growth rate of cyanobacteria strains.

\begin{tabular}{|c|c|c|c|c|}
\hline \multirow{2}{*}{$\begin{array}{l}\text { Response Variable } \\
\text { (Growth Rate, day }^{-1} \text { ) }\end{array}$} & \multicolumn{4}{|c|}{ Factor } \\
\hline & IP & IN & $\mathbf{N}: \mathbf{P}$ & $\mathbf{I P} \times \mathbf{N}: \mathbf{P}$ \\
\hline Cyanobacteria & $F_{(32,75)}=126.56^{* *}$ & $F_{(112,151)}=35.23 * *$ & $F_{(16,40)}=142.79 * *$ & $F_{(64,121)}=11.10 * *$ \\
\hline Species & $F_{(15,168)}=54.31 * *$ & $F_{(45,9)}=35.94 *$ & $F_{(9,270)}=554.91^{* *}$ & $p>0.05$ \\
\hline Strain & $F_{(35,242)}=34.11 *$ & $F_{(91,14)}=38.13^{*}$ & $F_{(21,307)}=24.19 *$ & $p>0.05$ \\
\hline Native/Alien & $F_{(5,63)}=4.01 *$ & $F_{(15,5)}=8.67^{* *}$ & $F_{(3,113)}=19.41 *$ & $p>0.05$ \\
\hline Planktothrix agardhii & $F_{(4,74)}=660.16^{*}$ & $F_{(14,74)}=321.83^{* *}$ & $F_{(2,74)}=800.00 *$ & $F_{(8,74)}=28.06^{*}$ \\
\hline Aphanizomenon gracile & $F_{(4,75)}=183.78^{*}$ & $F_{(14,75)}=54.44^{* *}$ & $F_{(2,75)}=6.03 *$ & $p>0.05$ \\
\hline Sphaerospermopsis aphanizomenoides & $F_{(4,73)}=226.29 *$ & $F_{(14,73)}=66.14^{* *}$ & $p>0.05$ & $p>0.05$ \\
\hline Chrysosporum bergii & $p>0.05$ & $p>0.05$ & $p>0.05$ & $p>0.05$ \\
\hline
\end{tabular}

$\mathrm{N}: \mathrm{P}, \mathrm{N}$ and $\mathrm{P}$ atomic ratio; ${ }^{*}, p<0.001 ;{ }^{* *}, p<0.01$.

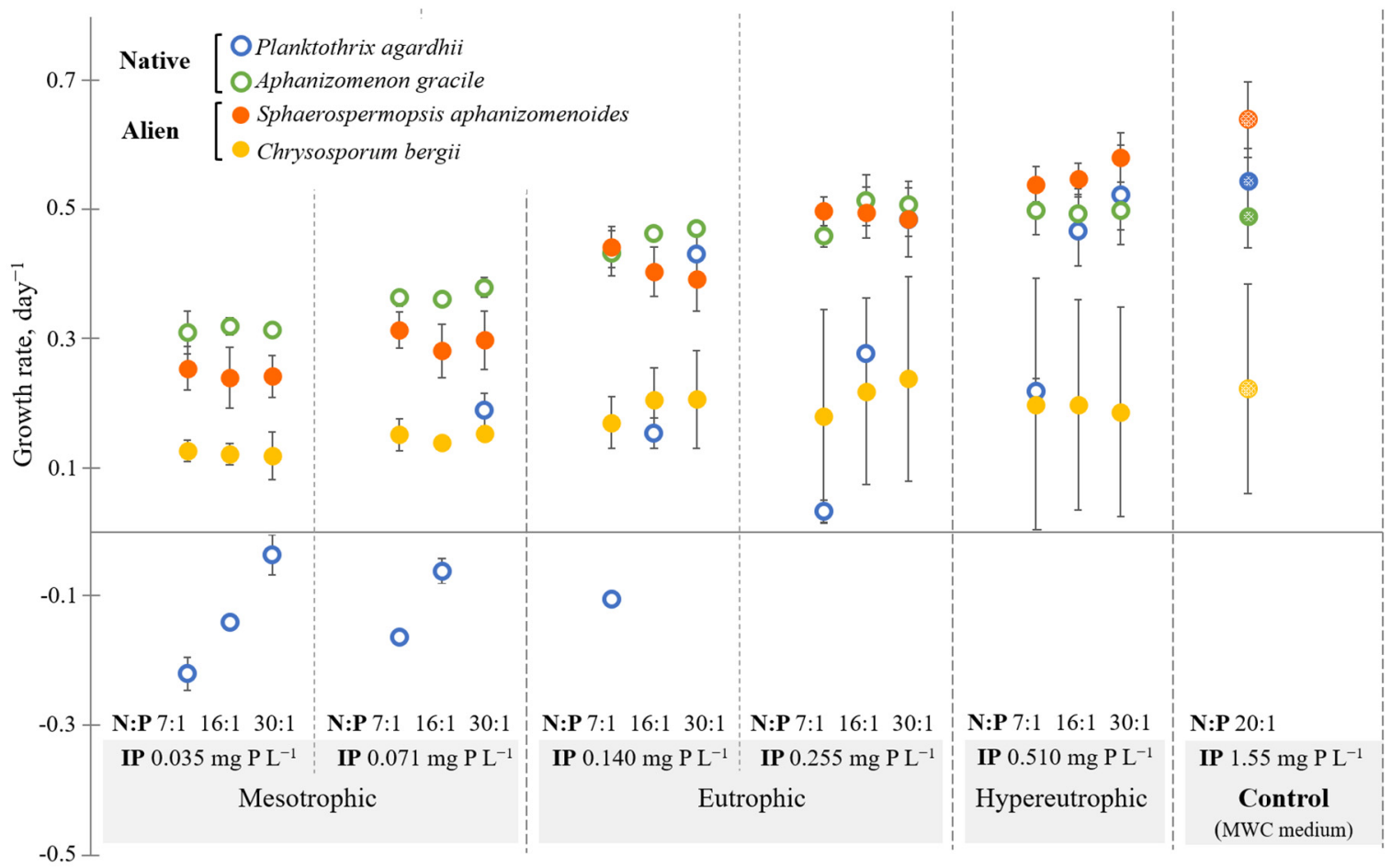

Figure 1. Growth rates $\left(\mathrm{day}^{-1}\right)$ of the cyanobacteria species cultured under different nutrient concentrations and N:P ratio at $24{ }^{\circ} \mathrm{C}$. Each symbol represents the average growth rate of two tested strains of each species at exponential growth phase. Data are reported as mean and error bars represent standard deviation.

\subsubsection{Effect of Nutrients on Production of Cyanometabolites}

The STX concentration in the experiment samples of the toxic Aphanizomenon gracile strain NRC_SIR/B41-09 ranged from 17.29 to $481.03 \mathrm{ng} \mathrm{g}^{-1}$ of freeze-dried weight (Figure 2). 
The highest toxin amount was detected at the lowest IP concentration $\left(0.035 \mathrm{mg} \mathrm{P} \mathrm{L}^{-1}\right)$ and at $\mathrm{N}: \mathrm{P}$ ratios 7:1 and 30:1. However, the regression analysis did not reveal a relationship between $A$. gracile growth rate, IP concentrations, N:P ratio to saxitoxin concentration $(p>0.05)$.

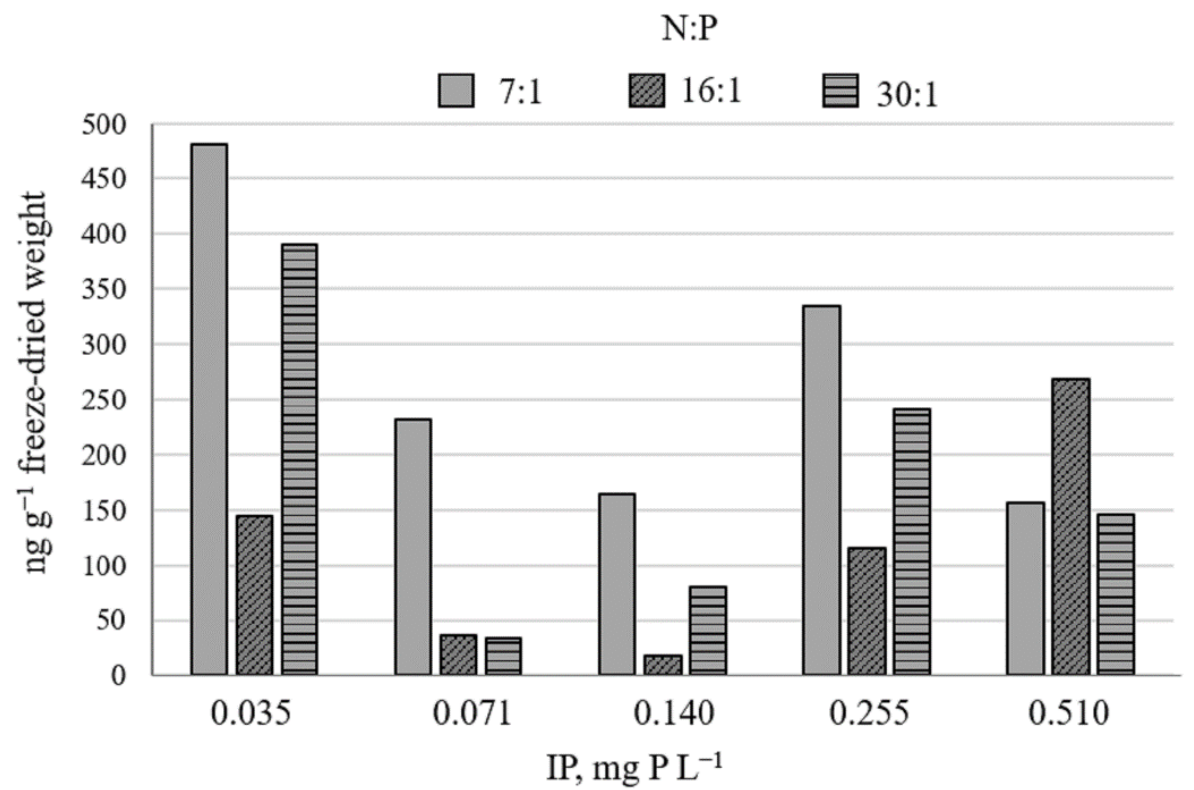

Figure 2. The amount of saxitoxin in Aphanizomenon gracile strain NRC_SIR/B41-09 grown under various IP concentrations and N:P ratio. Column represents cyanotoxin concentration in intermixed triplicate $(n=3)$ of each tested treatment.

Total MCs concentration in the toxic Planktothrix agardhii strain NRC_SIR/F5-09 ranged from $9.83 \times 10^{4}$ to $1.16 \times 10^{6} \mathrm{ng} \mathrm{g}^{-1}$ freeze-dried weight (Figure 3). The proportion of MCs variants slightly varied in all tested treatments. The demethylated microcystin RR (dmMC-RR) and demethylated microcystin LR (dmMC-LR) prevailed, and the highest content of the toxins was determined at the IP concentration $0.140 \mathrm{mg} \mathrm{P} \mathrm{L}^{-1}$. The dmMC-RR content was up to 1.8 -fold higher than dmMC-LR.

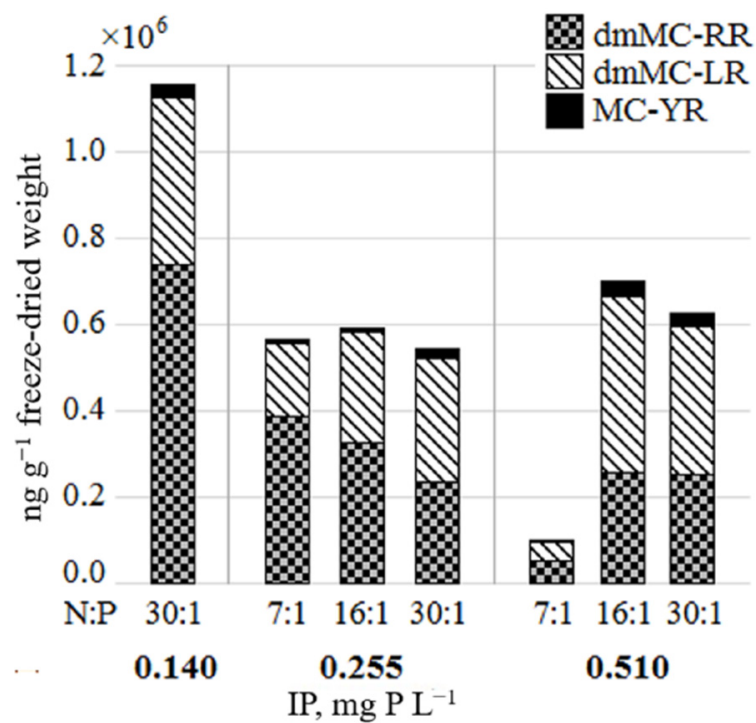

Figure 3. The amount of microcystins in toxic Planktothrix agardhii strain NRC_SIR/F5-09 under the tested IP concentrations and N:P ratio. Column represents cyanotoxins concentration in intermixed triplicate $(n=3)$ of each tested treatment. 
Three oligopeptide classes, anabaenopeptins (APs), aeruginosins (AERs) and cyanopeptolins (CPs), were detected in P. agardhii toxic and nontoxic strains used in the experiment (Figure 4). APs and AERs were predominant and shared approximately an equal part of the total amount in the toxic strain. Contrary, AERs dominated over APs in the nontoxic strain. The relative total concentration of all oligopeptides in the nontoxic P. agardhii strain was up to 3-fold higher than in the toxic strain under all examined treatments.

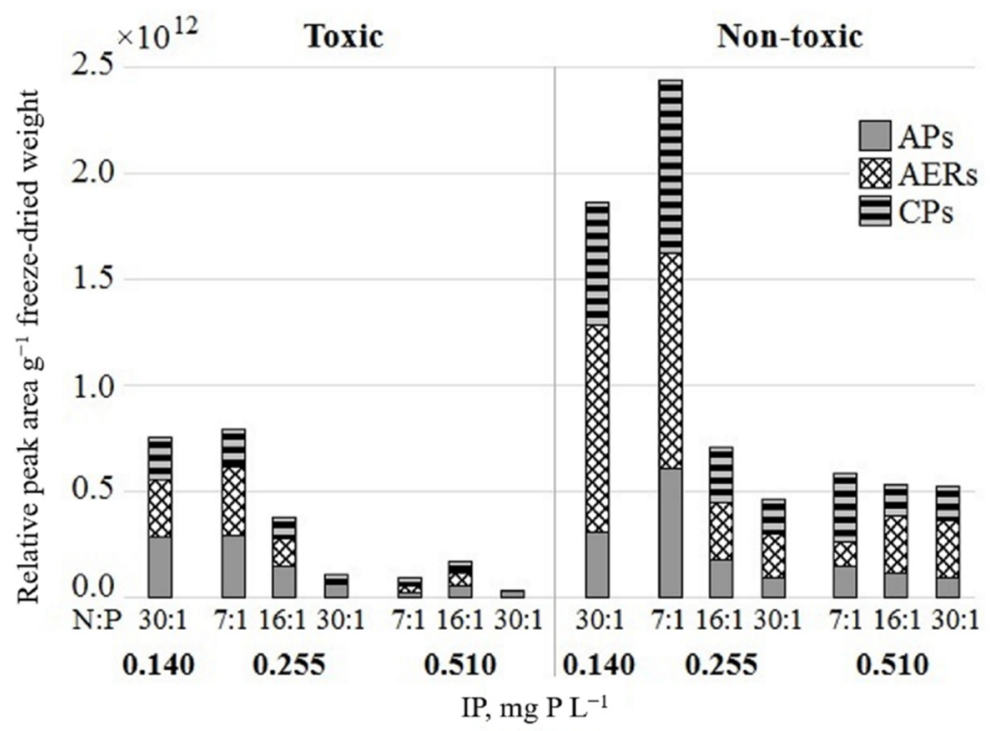

Figure 4. Relative number of oligopeptides in the biomass of toxic and nontoxic Planktothrix agardhii strains under the tested IP concentrations and N:P ratio. Classes of oligopeptides: APsanabaenopeptins, AERs-aeruginosins, CPs—cyanopeptolins. Column represents oligopeptides amount in intermixed triplicate $(n=3)$ of each tested treatment.

The regression analysis revealed a strong negative relationship between IP and dmMC$\mathrm{RR}, \mathrm{APs}, \mathrm{CPs}$ concentrations in toxic P. agardhii strain $(r=-0.86, r=-0.81$ and $r=-0.85$, $p<0.05$, respectively), whereas dmMC-LR, MC-YR correlated positively $(r=0.78, r=0.82$, $p<0.05$, respectively). The growth rate of nontoxic $P$. agardhii strain negatively correlated with relative amount of APs and CPs $(r=-0.82, r=-0.78, p<0.05$, respectively).

The tested P. agardhii strains formed insufficient biomass at lower IP concentrations required for the analysis of secondary metabolites, and that prevented us from drawing clear conclusions on the nutrient effect on MCs and NRPs variation.

\subsection{Experiment II: Interspecies Competition}

The results of GLM analysis of biomass values on the final day of the experiment showed that nutrient (IP and IN) concentrations followed by temperature and species origin had the greatest effect on cyanobacteria species competition (Table 2). For native Planktothrix agardhii important factors were nutrients (IP and IN, $F_{(1,16)}=37.33, p<0.001$ ) and alien species $\left(F_{(1,16)}=9.05, p<0.01\right)$, whereas for native Aphanizomenon gracile they were nutrients $\left(F_{(1,16)}=16.44, p<0.001\right)$ and temperature $\left(F_{(1,16)}=6.86, p<0.05\right)$. For alien Sphaerospermopsis aphanizomenoides, all the tested factors were significant (Table 2), whereas for Chrysosporum bergii only temperature was not a significant factor $(p>0.05)$. 
Table 2. General linear model (GLM) results for factors' impact on the response variable biomass of cyanobacteria strains.

\begin{tabular}{|c|c|c|c|c|c|c|}
\hline \multirow{2}{*}{ 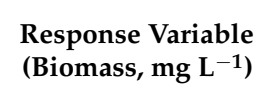 } & \multicolumn{6}{|c|}{ Factor } \\
\hline & IP and IN & $\mathrm{T}$ & Species & Alien & Native & $\mathrm{T} \times \mathrm{IP}$ and $\mathrm{IN}$ \\
\hline \multirow{5}{*}{$\begin{array}{c}\text { Cyanobacteria } \\
\text { Planktothrix agardhii } \\
\text { Aphanizomenon gracile } \\
\text { Sphaerospermopsis } \\
\text { aphanizomenoides } \\
\text { Chrysosporum bergii }\end{array}$} & $F_{(1,112)}=29.50^{*}$ & $F_{(1,112)}=23.10 *$ & $F_{(3,112)}=14.02 *$ & & & $F_{(1,112)}=15.44^{*}$ \\
\hline & $F_{(1,16)}=37.33^{*}$ & $p>0.05$ & & $F_{(1,16)}=9.05^{* *}$ & & $p>0.05$ \\
\hline & $F_{(1,16)}=16.44^{*}$ & $F_{(1,16)}=6.86^{* * *}$ & & $p>0.05$ & & $F_{(1,16)}=5.23^{* * *}$ \\
\hline & $F_{(1,16)}=74.46^{*}$ & $F_{(1,16)}=70.46^{*}$ & & & $F_{(1,16)}=61.18^{*}$ & $F_{(1,16)}=45.31$ * \\
\hline & $F_{(1,16)}=7.11^{* * *}$ & $p>0.05$ & & & $F_{(1,16)}=6.16^{* * *}$ & $F_{(1,16)}=14.60 * *$ \\
\hline
\end{tabular}

T, temperature; IP and IN, IP with N:P ratio of $30 ;{ }^{*}, p<0.001 ; * *, p<0.01 ; * * *, p<0.05$.

Native $P$. agardhii and $A$. gracile competed for nutrients, especially in the treatments with higher IP and IN concentration (Figure 5). At the elevated nutrient concentrations and $24{ }^{\circ} \mathrm{C}$ temperature, the biomass of co-cultured $A$. gracile was 2.5 times higher $\left(59.7 \mathrm{mg} \mathrm{L}^{-1}\right)$ compared to $P$. agardhii $\left(23.7 \mathrm{mg} \mathrm{L}^{-1}\right)$. Compared to controls, A. gracile biomass in co-culture was approximately similar; however, the biomass of P. agardhii was 3-6.5 times lower in the treatments with higher IP and IN concentrations. This indicated that P. agardhii growth was suppressed by A. gracile.
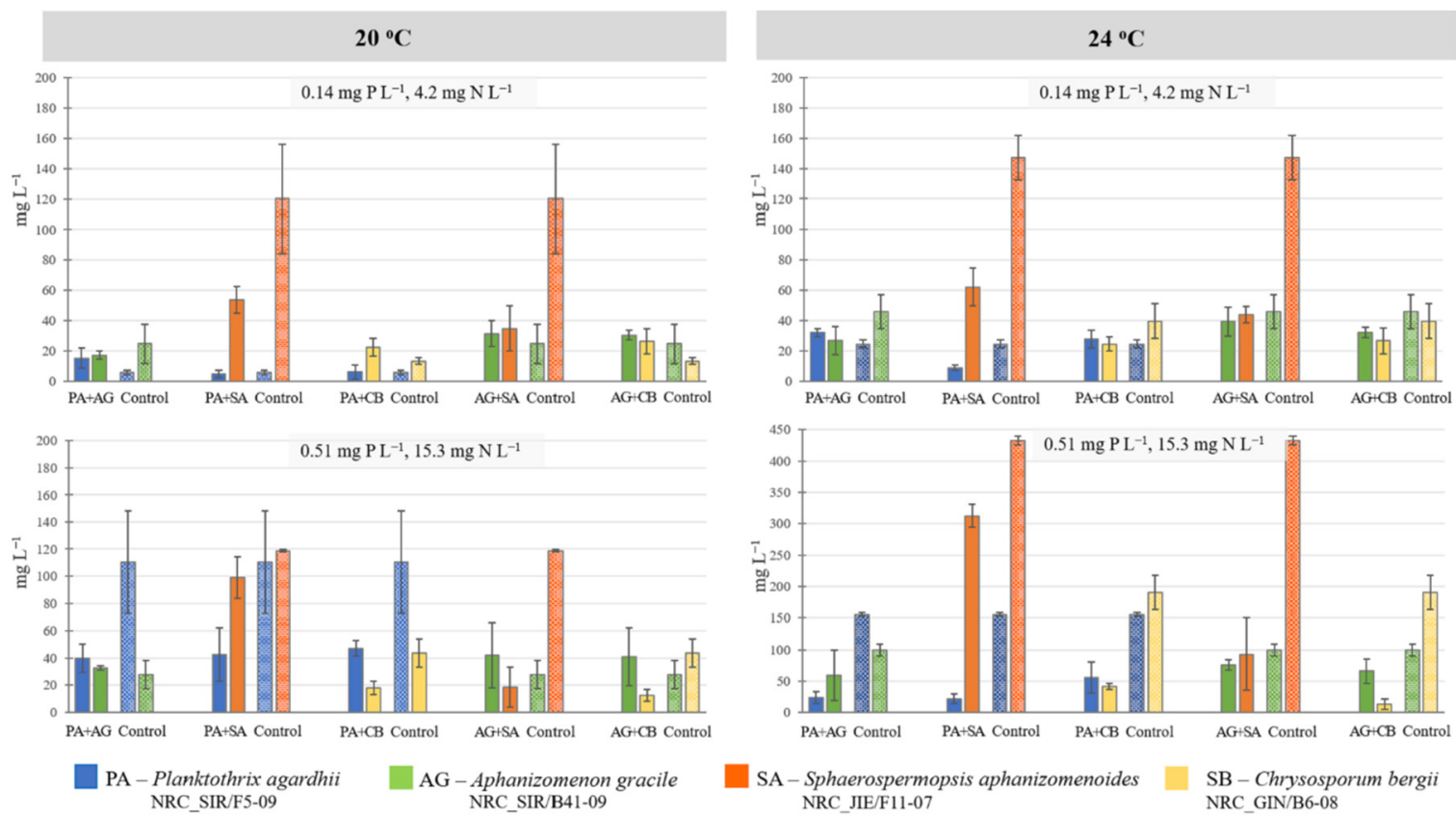

Figure 5. Biomass of co-cultured native toxins producing Planktothrix agardhii, Aphanizomenon gracile, and alien nontoxic Sphaerospermopsis aphanizomenoides, Chrysosporum bergii strains under different temperatures and IP concentrations (N:P ratio 30:1). Control strains were grown separately in the same medium and the selected temperature. Data are reported as mean and error bars represent standard deviation.

Interactions among native and alien species were species-specific. The statistical analysis showed that alien species significantly affected growth of $P$. agardhii $\left(F_{(1,16)}=9.05\right.$, $p<0.01)$; however, the effect of alien $S$. aphanizomenoides was more obvious compared to C. bergii. The biomass of co-cultured P. agardhii was 2.3-14 times lower compared to S. aphanizomenoides, especially in the treatment with elevated nutrient concentrations at $24{ }^{\circ} \mathrm{C}\left(21.8 \mathrm{mg} \mathrm{L}^{-1}\right.$ vs. $\left.312 \mathrm{mg} \mathrm{L}^{-1}\right)$ (Figure 5). Co-cultured P. agardhii biomass was up to seven times lower compared to controls, while only a slight decrease of the biomass was seen for S. aphanizomenoides.

Availability of nutrients and temperature rather than interspecies competition had an effect on P. agardhii and C. bergii growth. P. agardhii biomass at elevated IP and IN concentrations was 2-7.4 times higher, whereas $C$. bergii built up the highest biomass in 
the treatments with high nutrients at $24{ }^{\circ} \mathrm{C}$ (Figure 5). Interspecies competition was more obvious in co-culture treatments at high nutrient concentrations and temperature, where species biomass was 2.8 and 4.6 times lower for P. agardhii and C. bergii, respectively.

A. gracile biomass in co-cultures was similar to $S$. aphanizomenoides and about two times higher than $C$. bergii (on average, $42.4 \mathrm{mg} \mathrm{L}^{-1}$ vs. $19.5 \mathrm{mg} \mathrm{L}^{-1}$ ) in most of the treatments. Higher nutrient concentrations predetermined a slight increase of $A$. gracile biomass and this was supported by GLM $\left(F_{(1,16)}=16.44, p<0.001\right.$ for IP and IN). At $20{ }^{\circ} \mathrm{C}$ temperature, A. gracile biomass in co-cultures with both alien cyanobacteria was 1.5 times higher than in the control treatments. Compared to the controls, S. aphanizomenoides biomass was 3.3-6.7 times lower, whereas $C$. bergii biomass was up to 15 times lower in co-cultures with native $A$. gracile. The assessment revealed that $A$. gracile did not suffer from alien species (Table 2), but had a negative effect on both alien species $\left(F_{(1,16)}=61.18, p<0.001\right.$ for $S$. aphanizomenoides; $F_{(1,16)}=6.16, p<0.05$ for $C$. bergii).

\section{Discussion}

Temperature along with eutrophication stimulate an increase in frequency, duration, and intensity of harmful cyanobacterial blooms in freshwaters [9,32]. It is widely shown that global warming induces the expansion and introduction of alien species to Europe, altering the structure and functioning of native communities [33,34]. As cyanotoxins' production in the water body is dependent on the contribution of toxigenic strains in cyanobacterial community, those changes might also lead to a shift in toxin composition and concentration. In the current study, the interplay of nutrients, temperature, and competition of native and alien cyanobacteria species growth, and cyanotoxin and/or other NRPs production were tested during complex controlled experiments with multiple factors and mixed species. The results discussed will give a better understanding about the complex role of abiotic and biotic variables, interspecies competition for the harmful cyanobacteria blooms, and species invasiveness to the temperate freshwaters under changing conditions.

\subsection{Cyanobacteria Growth Response to Nutrients}

The experimental studies revealed that nutrients (N:P ratio, IN, IP) were the key factors determining the growth rate of tested native and alien to Europe cyanobacteria. The response of cyanobacteria species to nutrients was species- and strain-specific. In addition, the environmental studies indicated that both phosphorus and nitrogen contributed and controlled the occurrence and intensity of the bloom [8-10,35,36], and the situation depends on the nutrient preferences of the potentially harmful cyanobacteria.

\subsubsection{Native Species Response}

The growth rate of $P$. agardhii was mostly affected by the N:P ratio, followed by the changes in IP and IN (Table 1). Eutrophic and hypertrophic conditions with the N:P ratio 30:1 were the most favorable, whereas tested mesotrophic and eutrophic conditions with the N:P ratio 7:1 and 16:1 clearly limited growth of the species (Figure 1). These results agree with the data of field studies where common dominance and blooms of $P$. agardhii in hypertrophic lakes have been found $[22,37,38]$. P. agardhii suffers from nitrogen limitation at $\mathrm{N}$ concentrations lower than $0.05 \mathrm{mg} \mathrm{L}^{-1}$ [21], but is favored by high concentrations of phosphorus [39].

Similarly, IP followed by IN was the most significant factor for another native species A. gracile (Table 1). A. gracile growth rate increased gradually with increasing IP concentration. Figueiredo et al. [40] reported that the growth of the Aphanizomenon flos-aquae was highly dependent on phosphorus rather than on nitrogen, possibly due to the species $\mathrm{N}_{2}$ fixing capability. Figueiredo et al. [41] also showed experimentally that variation in nitrate level did not significantly affect the growth of $A$. gracile. In lakes, A. gracile thrive under nitrogen-deficient conditions [21] and at a high N:P ratio [15]. It suggests that $A$. gracile is highly adapted to various environmental conditions. The species is referred as a typical 
cyanobacterium for the temperate region and is characterized as a frequent dominant accompanied by other co-occurring prevailing species [21,30].

\subsubsection{Alien Species Response}

Alien species responded differently to the varied nutrient concentrations. The experiment revealed that IP had a strong effect on the growth of the S. aphanizomenoides followed by IN. This is in agreement with Sabour et al. [42], who showed experimentally the maximum growth rate of S. aphanizomenoides under the highest nutrient concentrations; however, on the contrary, species reached an optimal growth rate at N:P ratios from 1 to 15 . Figueiredo et al. [41] found that $S$. aphanizomenoides was moderately to extremely sensitive to nitrate depletion in the medium. This also supports the findings by Budzyńska and Gołdyn [43] from field studies as S. aphanizomenoides was characterized as a high-nutrient demanding species.

The current study disclosed that the growth potential of $C$. bergii was strain-specific, especially under hypertrophic conditions (Figure 1). Nutrient concentration and N:P ratio were not significant factors for C. bergii (Table 1). Other studies indicated that C. bergii preferred low concentrations of inorganic phosphorus and the species was the most powerful competitor among Nostocales at moderate $\left(19-20^{\circ} \mathrm{C}\right)$ temperatures $[24,44]$. On the contrary, Savadova et al. [29] revealed that the species has a preference for higher $\left(26-30^{\circ} \mathrm{C}\right)$ temperatures. This indicates that temperature rather than nutrients could be a limiting factor for the species proliferation in Lithuanian water bodies as it remains at low biomass in Lake Gineitiškès since 2008 (up to $0.26 \mathrm{mg} \mathrm{L}^{-1}$ [28]). In addition, it can explain the slow C. bergii spread northwards as only single filaments were found in Lake Rèkyva in 2014, the northernmost point of species distribution in Europe (unpublished data).

\subsection{Cyanometabolites Production in Response to Nutrients}

The stoichiometric theory of phytoplankton toxin regulation has stated that $\mathrm{N}$ limitation causes a reduction of $\mathrm{N}$-rich toxins, whereas $\mathrm{P}$ shortage causes an increase in the most $\mathrm{N}$-rich saxitoxins and the limitation of both nutrients promotes the C-rich toxins [45]. However, prediction of toxin type and concentrations in nutrient surplus conditions possibly does not follow those rules and is even more difficult to forecast.

Information on factors that regulate saxitoxin production in cyanobacteria is very limited. Kellmann et al. [46] analyzed the STX gene cluster in cyanobacteria and concluded that the target toxin synthesis may be regulated at the transcriptional level in response to the availability of phosphate and other environmental factors. The concentration of STX was notably higher in the biomass of Raphidiopsis raciborskii strain grown under oligotrophic rather than a super-eutrophic condition [47]. Nevertheless, though a similar tendency was observed in the current experiment, a significant relationship of Aphanizomenon gracile growth rate, IP concentrations, N:P ratio to STX concentrations was not revealed $(p>0.05)$.

A high variety of the MCs and bioactive non-ribosomal peptides was detected in scum samples of $P$. agardhii [48]. The current experimental study demonstrated that the toxic $P$. agardhii strain was able to produce three different variants of the MCs, and the shift in the proportion of MCs variants under varied nutrient conditions was not observed. Total concentration of the MCs was two times higher under eutrophic compared to hypertrophic conditions, but the total amount of toxins was not affected by the different N:P ratio. Therefore, these data cannot confirm the findings [16,49] that under $\mathrm{N}$ enrichment conditions higher MCs production is expected. Overall, complex environmental conditions (e.g., irradiance) rather than nutrients alone regulate mcy genes expression, and probably MCs production is mostly related to cell division and growth [50-52].

In the present study, tested P. agardhii strains produced APs, AERs and CPs, and the total amount of those NRPs was three-fold higher in nontoxic strain compared to MCs-producing strain. Our results are consistent with the data from other studies that highlighted co-production of various peptides with MCs in P. agardhii and the finding that 
strains lacking MC production contain other structurally related peptides that could play complementary [52].

Paerl et al. [53] concluded that toxin concentrations tend to be closely correlated with growth rate and cell abundance, and the factors that stimulate toxin biosynthesis may be group- or strain-specific. Nevertheless, the experiments revealed some regularities concerning the amount of the STX, MCs and other NRPs in relation to nutrient changes; however, further studies are needed to clarify the conclusions on this issue.

\subsection{Combined Effect of Environmental Factors on Interspecies Competition}

Competition is an important regulatory factor for community dynamics. The interspecies variation plays a crucial role in bloom dynamics; however, competition mechanisms between the different bloom-forming cyanobacteria species are poorly understood $[41,54]$. Eutrophication and climate warming simultaneously affect cyanobacteria community in natural ecosystems [32]. More complex and definitive suite experiments instead of the approaches focused on single stressors and individual species can more effectively capture the regularities of processes driven by eutrophication and a changing climate [55]. Laboratory culture and field experiments are the first steps towards understanding phytoplankton communities' functioning and also can improve the confidence of predicting the success of alien species invasion.

The results of the current experiment revealed that IP together with IN concentrations had the greatest effect on cyanobacteria species competition, followed by temperature and species origin (Table 2). Native A. gracile suppressed growth of native P. agardhii and both alien species (Figure 5). Both native species evolved adaptations that help them to proliferate under nutrient-limiting conditions. P. agardhii can store nitrogen in a form of cyanophycin or phycocyanin [19] and surplus polyphosphate [56], whereas A. gracile can fix atmospheric $\mathrm{N}_{2}$ in heterocytes [57]. Teubner et al. [58] showed in field study that Aphanizomenon flos-aquae reached high biovolumes only when TN:TP $<16: 1$, while the growth of $P$. agardhii seems to be independent of seasonal variation of the TN:TP ratio. Our experiment did not reveal a significant dependence of the species competition on the N:P ratio. Possibly other factors or metabolites of $A$. gracile may significantly affect $P$. agardhii growth. It was found that an exudate of $A$. gracile had a cytotoxic effect on human neutrophiles [59] and the species extracts can induce cholinesterase activity in the fish brain homogenate [60]. More studies should be conducted to disclose the mechanisms of the interactions among the studied species.

The aim of the competition experiment was to assess the potential of alien cyanobacteria to outcompete native species that are dominant in eutrophic freshwaters of the temperate zone under ambient and elevated temperatures. The interspecies competition study under two different temperatures and IP concentrations revealed Sphaerospermopsis aphanizomenoides as a stronger invader compared to Chrysosporum bergii. Similarly, S. aphanizomenoides reached the highest growth rates and was the most powerful competitor followed by Raphidiopsis raciborskii, Aphanizomenon gracile, and C. bergii cyanobacteria in the experimental study performed by Mehnert et al. [44]. According to Savadova et al. [29], S. aphanizomenoides tolerated a wide range of temperatures $\left(20-30{ }^{\circ} \mathrm{C}\right)$, and growth rate was one of the highest between tested native and alien cyanobacteria. These abilities probably predetermined increased proliferation and dominance of the species in temperate lakes $[23,24,26]$. The current experiment revealed that $S$. aphanizomenoides was a superior competitor over $P$. agardhii under elevated nutrient concentrations at $24^{\circ} \mathrm{C}$, but not in the case of $A$. gracile, which may suppress the establishment of alien cyanobacteria in temperate lakes. Several studies indicated the importance of secondary metabolites in the interspecies competition among cyanobacteria [54,61-63]. However, there is no evidence that alien species in Europe such as Raphidiopsis raciborskii can produce cyanotoxins [59]. Kokociński and Soininen [24] found a negative relationship between the native $A$. gracile biomass and the biomass of alien Chrysosporum bergii from field data analysis. Similarly, our experiment 
demonstrated a negative effect of STX producing A. gracile strain on other tested native $P$. agardhii and nontoxic alien cyanobacteria species isolated from the lakes in Lithuania.

\section{Conclusions}

Both native Planktothrix agardhii, Aphanizomenon gracile, and alien to Europe Sphaerospermopsis aphanizomenoides species successfully proliferated under elevated IP and IN conditions, whereas a high N:P ratio (30:1) was significant only for non-diazotrophic P. agardhii. The highest growth rate was detected for native $A$. gracile and alien S. aphanizomenoides under eutrophic-hypertrophic conditions, indicating the reason for their success in climate change conditions. The alien Chrysosporum bergii growth potential was not affected by nutrients.

A strain of native A. gracile species had the ability to produce STX, whereas P. agardhiia complex of bioactive oligopeptides. The P. agardhii strain producing three variants of MCs (dmMC-RR, dmMC-LR, and MC-YR) had a 3-fold lower amount of other NRPs compared to MCs non-producing strain. The experiment showed that IP was important for the amount of MCs and/or other NRPs produced in different treatments. However, for both species further research is needed to determine the relationships between increase in nutrient concentration and toxin production.

The greatest effect on interspecies competition was under increased temperature coupled with elevated nutrient concentrations. Alien species of cyanobacteria differ by their invading abilities into native populations of temperate lakes. S. aphanizomenoides was a stronger invader compared to $C$. bergii. This study also showed that native cyanobacteria A. gracile can suppress establishment of alien species under warming and eutrophication conditions.

\section{Materials and Methods}

\subsection{Experimental Approach}

Two types of experiments were performed to assess nutrient effects on (i) cyanobacteria growth and toxic metabolites production and (ii) species competitive abilities, using eight strains belonging to potentially toxic native and nontoxic alien cyanobacteria that were isolated from Lithuanian lakes. Four of them were native strains: Planktothrix agardhii MCs producing and non-producing (further toxic and nontoxic strains, accordingly) and Aphanizomenon gracile STX producing and non-producing strains (further toxic and nontoxic strains, accordingly) (Table 3). Cyanobacteria species were identified and classified based on morphology after Komárek and Anagnostidis [64], Komárek [65]. The selected conditions in controlled growth chambers were $\sim 90 \mu \mathrm{mol} \mathrm{m}^{-2} \mathrm{~s}^{-1}$ of light intensity and 16:8 light: dark day cycle. Illumination condition was chosen based on light preferences of native P. agardhii [66] and A. gracile [44] species. Cultures were grown in triplicate in Erlenmeyer flasks of $100 \mathrm{~mL}$ volume. The tested strains were re-isolated before the experiments to ensure low density of bacteria $(<1 \%)$. Prior to the experiment, the strains were maintained for three days in MWC medium free of $\mathrm{N}$ and $\mathrm{P}$ elements at respective temperatures. An initial concentration of chlorophyll- $a$ (chl- $a) 10 \pm 0.5 \mu \mathrm{g} \mathrm{L}^{-1}$ was used for all treatments, which reflected prebloom conditions according to WHO [2]. Flasks were manually mixed once a day during the 12-day experimental period. 
Table 3. Cyanobacteria strains selected for the experiments.

\begin{tabular}{|c|c|c|c|c|c|}
\hline & Species & Strain & Lake & Cyanotoxins and NRPs & Other NRPs \\
\hline \multirow{4}{*}{ Native } & \multirow{2}{*}{ Planktothrix agardhii } & NRC_SIR/F5-09 & Širvys & MCs & NRPs \\
\hline & & NRC_JIE/E9-07 & Jieznas & - & NRPs \\
\hline & \multirow{2}{*}{ Aphanizomenon gracile } & NRC_SIR/B41-09 & Širvys & STX & - \\
\hline & & NRC_SIR/C10-07 & Širvys & - & - \\
\hline \multirow{4}{*}{ Alien } & \multirow{2}{*}{$\begin{array}{l}\text { Sphaerospermopsis } \\
\text { aphanizomenoides }\end{array}$} & NRC_JIE/G11-07 & Jieznas & - & - \\
\hline & & NRC_JIE/F11-07 & Jieznas & - & - \\
\hline & \multirow{2}{*}{ Chrysosporum bergii } & NRC_REK/D2-08 & Rèkyva & - & - \\
\hline & & NRC_GIN/B6-08 & Gineitiškès & - & - \\
\hline
\end{tabular}

MCs, microcystins; NRPs, non-ribosomal peptides; STX, saxitoxin; - , not detected.

\subsection{Experiment I: Effect of the Nutrients}

The experiment was carried out to examine the effect of inorganic nitrogen (IN) and phosphorus (IP) concentrations, their atomic ratio (N:P) on the growth rate of cyanobacteria strains as well as on production of cyanotoxins and other non-ribosomal peptides (NRPs) (further cyanometabolites). Nitrogen and phosphorus free MWC medium was supplemented by phosphorus in the form of $\mathrm{K}_{2} \mathrm{HPO}_{4}$ at five different concentrations characteristic to temperate lakes of various trophy (based on Wetzel [67]): concentration $0.035 \mathrm{mg} \mathrm{P} \mathrm{L}^{-1}$ corresponded to mesotrophic lakes, 0.071 and $0.140 \mathrm{mg} \mathrm{P} \mathrm{L}^{-1}$ to eutrophic lakes, and 0.255 and $0.51 \mathrm{mg} \mathrm{P} \mathrm{L}^{-1}$ to hypertrophic lakes (Figure 6). Nitrogen was added to the treatments in the form of $\mathrm{NaNO}_{3}$ according to $\mathrm{N}: \mathrm{P}$ atomic ratio of 7:1; 16:1 and 30:1. Control treatments contained MWC medium (N:P atomic ratio 20:1, $1.55 \mathrm{mg} \mathrm{P} \mathrm{L}^{-1}$ ). A temperature of $24{ }^{\circ} \mathrm{C}$ was chosen based on the results described in Savadova et al. [29]. The growth rate $(\mu)$ was evaluated by measuring chlorophyll- $a$ content at the exponential growth phase of the strain using an AlgaeLabAnalyser (bbe Moldaenke GmbH, Schwentinental, Germany). At the end of the experiment, triplicate of each treatment of cyanometabolite producing strain were mixed in one sample, centrifuged at $8000 \times g$ for $6-12 \mathrm{~min}$. supernatant was removed, and the biomass was freeze-dried. The obtained material was used to evaluate cyanotoxins and other NRPs.

P. agardhii, A. gracile, S. aphanizomenoides, C. bergii

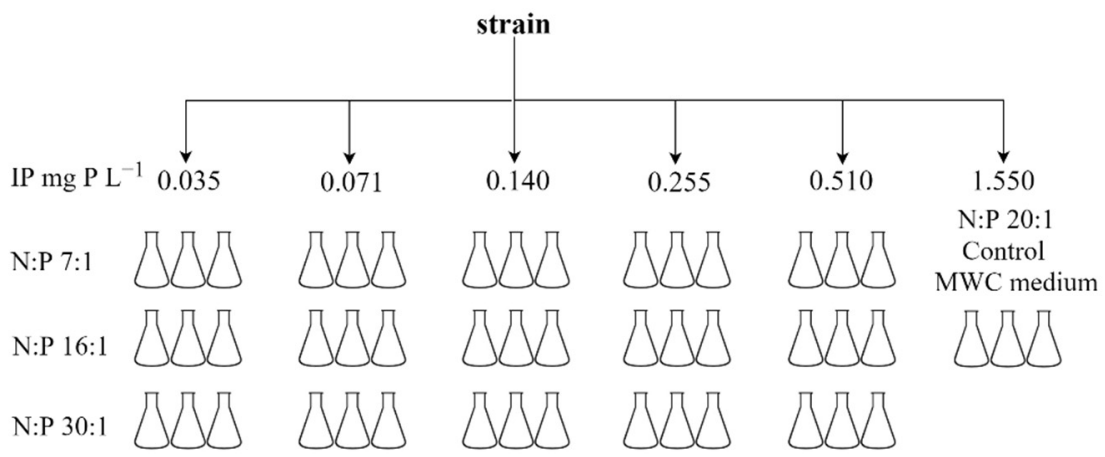

Figure 6. Schematic design of the experiment to test the effect of nutrients concentration on the growth rate and production of cyanotoxins and other NRPs of cyanobacteria strains.

5.2.1. Evaluation of Growth Rate of Cyanobacteria Strains

The growth rate (chl- $a$ day ${ }^{-1}$ ) was calculated according to Equation (1):

$$
\mu=\ln \left(\mathrm{N}_{\mathrm{t}}-\mathrm{N}_{0}\right) / \Delta \mathrm{t}
$$


where $\mathrm{N}_{0}$ and $\mathrm{N}_{\mathrm{t}}$-chl- $a$ values at the beginning and the end of the exponential growth phase, and $\Delta t$ is the period of the exponential phase expressed in days [68].

\subsubsection{Analysis of Cyanometabolites}

Freeze-dried cyanobacteria material was used for the analysis of intracellular amount of cyanometabolites. The extraction of microcystins (MCs) and other NRPs was performed using $75 \%$ methanol in MiliQ water. The saxitoxin (STX) was extracted with a mixture containing $4 \mathrm{mM}$ ammonium formate buffer ( $\mathrm{pH} 3.5$ ) and acetonitrile $(95: 5, v / v)$ at a ratio of 2:3. All samples were disrupted by vortexing for $5 \mathrm{~min}$ and maintained for $5 \mathrm{~min}$ in a bath sonicator (Bandelin, Berlin, Germany), centrifuged at 10,000 $\times g$ for $20 \mathrm{~min}$, and the supernatant was transferred to chromatographic vials. The analysis was performed using liquid chromatography tandem with mass spectrometer LC-MS/MS (AB Sciex. Concorde, ON, Canada) equipped with a turbo ion spray ionization, operating in positive mode using the information-dependent acquisition method (IDA) for the detection of NRPs as described in Grabowska et al. [22]. The identification of NRPs (aeruginosins, anabaenopeptins, cyanopeptolins) was performed based on the enhanced ion product spectra. The relative amount of the NRPs was estimated and provided as the peak area in the extracted ion chromatogram. MCs quantitative analysis was performed by MRM (Multiple Reaction Monitoring) using standards for MC-LR, MC-RR, dmMC-LR, dmMCRR, MC-YR, MC-LA, MC-LY, MC-LW, MC-LF variants (Alexis Biochemicals, San Diego, CA, USA). Detailed methodology presented in Khomutovska et al. [69]. Saxitoxin detection and quantitative analysis was conducted in MRM as described in Karosienè et al. [30] using STX standard (National Research Council, Halifax, Canada). Data were analyzed using Analyst QS ${ }^{\circledR} 1.5 .1$ software.

\subsection{Experiment II: Interspecies Competition}

Competitive properties of native P. agardhii and A. gracile cyanobacteria species and their ability to cope with alien S. aphanizomenoides and C. bergii under current $\left(20^{\circ} \mathrm{C}\right)$ climate conditions and in predicted warming $\left(24^{\circ} \mathrm{C}\right)$ and eutrophication scenarios (P 0.140; $0.51 \mathrm{mg} \mathrm{P} \mathrm{L}^{-1}$ at N:P ratio of 30:1) were assessed. Toxic strains of native species of P. agardhii NRC_SIR/F5-09 (MCs producer) and A. gracile NRC_SIR/B41-09 (STX producer) were co-cultured together in one experimental setup with alien species $S$. aphanizomenoides NRC_JIE/F11-07 and C. bergii NRC_GIN/B6-08 strains. The control was each strain grown separately in the same medium and selected temperatures (Figure 7). The aliquot of $1 \mathrm{~mL}$ was removed from each treatment every fourth day and preserved with formaldehyde at the final concentration of $4 \%$. The biomass changes were obtained by counting not less than 100 units ( 1 unit- $100 \mu \mathrm{m}$ of the filament) using Nageotte chamber with a light microscope [70]. Biomass was calculated based on the counted filaments number and mean filaments volumes using formulae for geometric shapes [71,72]. 


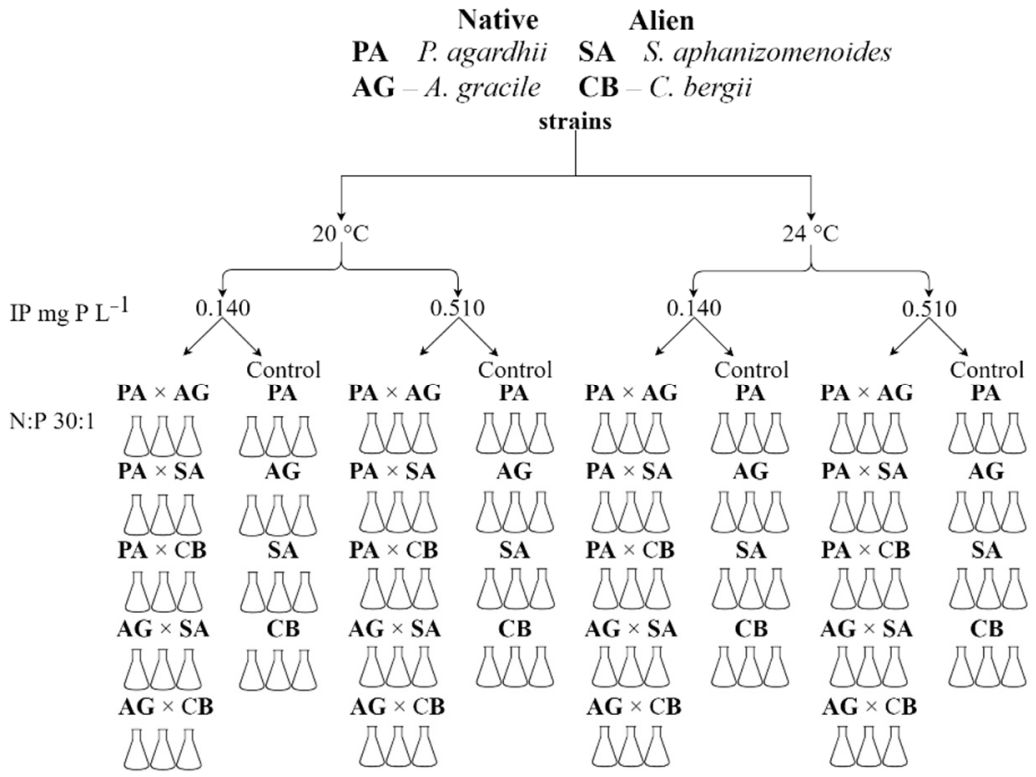

Figure 7. Schematic design of interspecies competition experiment.

\subsection{Statistical Analysis}

General linear model (GLM) analysis was performed to analyze data of experiments and to reveal significant effects of the tested factors and their interactions on growth rate or biomass of the tested strains. The linear regression was used to assess the relationship between abiotic factors and cyanobacteria biomass, and the concentration of secondary metabolites. Before analysis all data were tested to satisfy normality assumption using Shapiro-Wilk tests. The transformation was not applied as the data were normally distributed. Statistical data analysis was processed using STATISTICA 6.0 software package (Stat Soft. Inc., Tulsa, OK, USA).

Author Contributions: Conceptualization, K.S.-R. and J.K. (Judita Koreivienè); Formal analysis, K.S.-R. and H.M.-M.; Funding acquisition, K.S.-R., H.M.-M. and J.K. (Judita Koreivienė); Investigation, K.S.-R., J.K. (Jūratė Karosienè), J.K. (Jūratė Kasperovičienè), R.P., I.V. and J.K. (Judita Koreivienè); Methodology, H.M.-M., J.K. (Jūratė Karosienè), J.K. (Jūratė Kasperovičienè), R.P. and J.K. (Judita Koreivienè); Resources, H.M.-M., R.P. and J.K. (Judita Koreivienè); Software, K.S.-R. and J.K. (Jūratė Karosienè); Supervision, J.K. (Judita Koreivienè); Visualization, K.S.-R., I.V. and J.K. (Judita Koreivienè); Writing—original draft, K.S.-R. and J.K. (Judita Koreivienè); Writing-review \& editing, K.S.-R., H.M.-M., J.K. (Jūratė Karosienè), J.K. (Jūratė Kasperovičienè), R.P., I.V. and J.K. (Judita Koreivienè). All authors have read and agreed to the published version of the manuscript.

Funding: This research was partially funded by the Short Term Scientific Mission (STSM) grant from the European Cooperation in Science and Technology (COST) Action ES1408: European Network for Algal Bioproducts (EUALGAE).

Acknowledgments: The authors are very grateful to Elliot Shubert for the linguistic editing, also to anonymous reviewers for valuable remarks and helpful comments.

Conflicts of Interest: The authors declare no conflict of interest. The funders had no role in the design of the study; in the collection, analyses, or interpretation of data; in the writing of the manuscript, or in the decision to publish the results.

\section{References}

1. Gkelis, S.; Zaoutsos, N. Cyanotoxin occurrence and potentially toxin producing cyanobacteria in freshwaters of Greece: A multi-disciplinary approach. Toxicon 2014, 78, 1-9. [CrossRef]

2. WHO. Guidelines for safe recreational water environments. In Coastal and Fresh Waters; World Health Organization: Geneva, Switzerland, 2003; Volume 1. 
3. Buratti, F.M.; Manganelli, M.; Vichi, S.; Stefanelli, M.; Scardala, S.; Testai, E.; Funari, E. Cyanotoxins: Producing organisms, occurrence, toxicity, mechanism of action and human health toxicological risk evaluation. Arch. Toxicol. 2017, 91, 1049. [CrossRef] [PubMed]

4. Kardinaal, W.E.A.; Janse, I.; Agterveld, M.K.-V.; Meima, M.; Snoek, J.; Mur, L.R.; Huisman, J.; Zwart, G.; Visser, P.M. Microcystis genotype succession in relation to microcystin concentrations in freshwater lakes. Aquat. Microb. Ecol. 2007, 48, 1-12. [CrossRef]

5. Meriluoto, J.; Blaha, L.; Bojadzija, G.; Bormans, M.; Brient, L.; Codd, G.A.; Drobac, D.; Faassen, E.J.; Fastner, J.; Hiskia, A.; et al. Toxic cyanobacteria and cyanotoxins in European waters-Recent progress achieved through the CYANOCOST Action and challenges for further research. Adv. Oceanogr. Limnol. 2017, 8, 161-178. [CrossRef]

6. Mantzouki, E.; Lürling, M.; Fastner, J.; Domis, L.d.S.; Wilk-Woźniak, E.; Koreivienè, J.; Seelen, L.; Teurlincx, S.; Verstijnen, Y.; Krzton, W.; et al. Temperature effects explain continental scale distribution of cyanobacterial toxins. Toxins 2018, 10, 156. [CrossRef] [PubMed]

7. Schindler, D.W. The dilemma of controlling cultural eutrophication of lakes. Proc. Royal Soc. B 2012, 279, 4322-4333. [CrossRef] [PubMed]

8. Paerl, H. Nutrient and other environmental controls of harmful cyanobacterial blooms along the freshwater-marine continuum. In Cyanobacterial Harmful Algal Blooms: State of the Science and Research Needs; Hudnell, H.K., Ed.; Springer Science \& Business Media: Berlin, Germany, 2008; Volume 619, pp. 216-241.

9. Paerl, H.W.; Huisman, J. Climate change: A catalyst for global expansion of harmful cyanobacterial blooms. Environ. Microbiol. Rep. 2009, 1, 27-37. [CrossRef]

10. Paerl, H.W.; Scott, J.T.; McCarthy, M.J.; Newell, S.E.; Gardner, W.; Havens, K.E.; Hoffman, D.K.; Wilhelm, S.W.; Wurtsbaugh, W.A. It takes two to tango: When and where dual nutrient $(\mathrm{N} \& \mathrm{P})$ reductions are needed to protect lakes and downstream ecosystems. Environ. Sci. Technol. 2016, 50, 10805-10813. [CrossRef]

11. Klausmeier, C.A.; Litchman, E.; Daufresne, T.; Levin, S.A. Optimal nitrogen-to-phosphorus stoichiometry of phytoplankton. Nature 2004, 429, 171-174. [CrossRef]

12. Paerl, H.W.; Gardner, W.S.; Havens, K.E.; Joyner, A.R.; McCarthy, M.J.; Newell, S.E.; Qin, B.; Scott, J.T. Mitigating cyanobacterial harmful algal blooms in aquatic ecosystems impacted by climate change and anthropogenic nutrients. Harmful Algae 2016, 54, 213-222. [CrossRef]

13. Paerl, H.W.; Fulton, R.S.; Moisander, P.H.; Dyble, J. Harmful freshwater algal blooms with an emphasis on cyanobacteria. Sci. World J. 2001, 1, 76-113. [CrossRef] [PubMed]

14. Paerl, H.W.; Xu, H.; Hall, N.S.; Zhu, G.; Qin, B.; Wu, Y.; Rossignol, K.L.; Dong, L.; McCarthy, M.J.; Joyner, A.R. Controlling Cyanobacterial Blooms in Hypertrophic Lake Taihu, China: Will Nitrogen Reductions Cause Replacement of Non- $\mathrm{N}_{2}$ Fixing by $\mathrm{N}_{2}$ Fixing Taxa? PLoS ONE 2014, 9, e113123. [CrossRef] [PubMed]

15. Dolman, A.M.; Rücker, J.; Pick, F.; Fastner, J.; Rohrlack, T.; Mischke, U.; Wiedner, C. Cyanobacteria and cyanotoxins: The influence of nitrogen versus phosphorus. PLoS ONE 2012, 7, e38757. [CrossRef] [PubMed]

16. Davis, T.W.; Harke, M.J.; Marcoval, M.A.; Goleski, J.; Orano-Dawson, C.; Berry, D.L.; Gobler, C.J. Effects of nitrogenous compounds and phosphorus on the growth of toxic and non-toxic strains of Microcystis during cyanobacterial blooms. Aquat. Microb. Ecol. 2010, 61, 149-162. [CrossRef]

17. Dembowska, E. Cyanobacterial blooms in shallow lakes of the Iławskie Lake District. Limnol. Rev. 2011, 11, 69-79. [CrossRef]

18. Donald, D.B.; Bogard, M.J.; Finlay, K.; Bunting, L.; Leavitt, P.R. Phytoplankton-specific response to enrichment of phosphorus-rich surface waters with ammonium, nitrate, and urea. PLoS ONE 2013, 8, e53277. [CrossRef] [PubMed]

19. Van de Waal, D.B.; Ferreruela, G.; Tonk, L.; Van Donk, E.; Huisman, J.; Visser, P.M.; Matthijs, H.C.P. Pulsed nitrogen supply induces dynamic changes in the amino acid composition and microcystin production of the harmful cyanobacterium Planktothrix agardhii. FEMS Microbiol. Ecol. 2010, 74, 430-438. [CrossRef]

20. Wells, M.L.; Trainer, V.L.; Smayda, T.J.; Karlson, B.S.O.; Trick, C.G.; Kudela, R.M.; Ishikawa, A.; Bernard, S.; Wulff, A.; Anderson, D.M.; et al. Harmful algal blooms and climate change: Learning from the past and present to forecast the future. Harmful Algae 2015, 49, 68-93. [CrossRef]

21. Mischke, U.; Nixdorf, B. Equilibrium phase conditions in shallow German lakes: How Cyanoprokaryota species establish a steady state phase in late summer. Hydrobiologia 2003, 502, 123-132. [CrossRef]

22. Grabowska, M.; Kobos, J.; Torunska-Sitarz, A.; Mazur-Marzec, H. Non-ribosomal peptides produced by Planktothrix agardhii from Siemianówka Dam Reservoir SDR (northeast Poland). Arch. Microbiol. 2014, 196, 697-707. [CrossRef]

23. Kokociński, M.; Mankiewicz-Boczek, J.; Jurczak, T.; Spoof, L.; Meriluoto, J.; Rejmonczyk, E.; Hautala, H.; Vehniäinen, M.; Pawełczyk, J.; Soininen, J. Aphanizomenon gracile (Nostocales), a cylindrospermopsin-producing cyanobacterium in Polish lakes. Environ. Sci. Pollut. Res. 2013, 20, 5243-5264. [CrossRef] [PubMed]

24. Kokociński, M.; Soininen, J. New insights into the distribution of alien cyanobacterium Chrysosporum bergii (Nostocales, Cyanobacteria). Phycol. Res. 2019, 67, 208-214. [CrossRef]

25. Kaštovský, J.; Hauer, T.; Mareš, J.; Krautová, M.; Bešta, T.; Komárek, J.; Desortová, B.; Heteša, J.; Hindáková, A.; Houk, V.; et al. A review of the alien and expansive species of freshwater cyanobacteria and algae in the Czech Republic. Biol. Invasions 2010, 12, 3599-3625. [CrossRef] 
26. Stüken, A.; Rücker, J.; Endrulat, T.; Preussel, K.; Hemm, M.; Nixdorf, B.; Karsten, U.; Wiedner, C. Distribution of three alien cyanobacterial species (Nostocales) in northeast Germany: Cylindrospermopsis raciborskii, Anabaena bergii and Aphanizomenon aphanizomenoides. Phycologia 2006, 45, 696-703. [CrossRef]

27. Kasperoviciene, J.; Koreiviene, J.; Paskauskas, R. Cyanoprocaryotes and microcystins dynamics in shallow hypertrophic lake (South Eastern Lithuania). Oceonol. Hydrobiol. Stud. 2005, 34, 93-104.

28. Koreivienė, J.; Kasperovičienè, J. Alien cyanobacteria Anabaena bergii var. limnetica Couté et Preisig from Lithuania: Some aspects of taxonomy, ecology and distribution. Limnologica 2011, 41, 325-333. [CrossRef]

29. Savadova, K.; Mazur-Marzec, H.; Karosienè, J.; Kasperovičienė, J.; Vitonytè, I.; Toruńska-Sitarz, A.; Koreivienė, J. Effect of Increased Temperature on Native and Alien Nuisance Cyanobacteria from Temperate Lakes: An Experimental Approach. Toxins 2018, 10, 445. [CrossRef]

30. Karosienè, J.; Savadova-Ratkus, K.; Toruńska-Sitarz, A.; Koreivienè, J.; Kasperovičienè, J.; Vitonytè, I.; Błaszczyk, A.; Mazur-Marzec, H. First report of saxitoxins and anatoxin-a production by cyanobacteria from Lithuanian lakes. Eur. J. Phycol. 2020, 55, 327-338. [CrossRef]

31. Antunes, J.T.; Leão, P.N.; Vasconcelos, V.M. Cylindrospermopsis raciborskii: Review of the distribution, phylogeography, and ecophysiology of a global invasive species. Front. Microbiol. 2015, 6, 473. [CrossRef]

32. O'Neil, J.M.; Davis, T.W.; Burford, M.A.; Gobler, C.J. The rise of harmful cyanobacteria blooms: The potential roles of eutrophication and climate change. Harmful Algae 2012, 14, 313-334. [CrossRef]

33. Kovats, R.S.; Valentini, R.; Bouwer, L.M.; Georgopoulou, E.; Jacob, D.; Martin, E.; Rounsevell, M.; Soussana, J.-F. Climate Change 2014: Impacts, Adaptation, and Vulnerability. Part B: Regional Aspects; Barros, V.R., Field, C.B., Dokken, D.J., Mastrandrea, M.D., Mach, K.J., Bilir, T.E., Chatterjee, M., Ebi, K.L., Estrada, Y.O., Genova, R.C., et al., Eds.; Cambridge University Press: Cambridge, UK; New York, NY, USA, 2014; pp. 1267-1326.

34. Sukenik, A.; Quesada, A.; Salmaso, N. Global expansion of toxic and non-toxic cyanobacteria: Effect on ecosystem functioning. Biodivers. Conserv. 2015, 24, 889-908. [CrossRef]

35. Conley, D.J.; Paerl, H.W.; Howarth, R.W.; Boesch, D.F.; Seitzinger, S.P.; Havens, K.E.; Lancelot, C.; Likens, G.E. Controlling eutrophication: Nitrogen and Phosphorus. Science 2009, 323, 1014-1015. [CrossRef] [PubMed]

36. Lewis, W.M.; Wurtsbaugh, W.A.; Paerl, H.W. Rationale for control of anthropogenic nitrogen and phosphorus in inland waters. Environ. Sci. Technol. 2011, 45, 10030-10035. [CrossRef] [PubMed]

37. Yéprémian, C.; Gugger, M.F.; Briand, E.; Catherine, A.; Berger, C.; Quiblier, C.; Bernard, C. Microcystin ecotypes in a perennial Planktothrix agardhii bloom. Water Res. 2007, 41, 4446-4456. [CrossRef] [PubMed]

38. Toporowska, M.; Ferencz, B.; Dawidek, J. Impact of lake-catchment processes on phytoplankton community structure in temperate shallow lakes. Ecohydrology 2018, 11, e2017. [CrossRef]

39. Kokociński, M.; Stefaniak, K.; Mankiewicz-Boczek, J.; Izydorczyk, K.; Soininen, J. The ecology of the invasive cyanobacterium Cylindrospermopsis raciborskii (Nostocales, Cyanophyta) in two hypereutrophic lakes dominated by Planktothrix agardhii (Oscillatoriales, Cyanophyta). Eur. J. Phycol. 2010, 45, 365-374. [CrossRef]

40. de Figueiredo, D.R.; Azeiteiro, U.M.; Esteves, S.M.; Gonçalves, F.J.M.; Pereira, M.J. Microcystin-producing blooms-A serious global public health issue. Ecotoxicol. Environ. Saf. 2004, 59, 151-163. [CrossRef]

41. de Figueiredo, D.R.; Gonçalves, A.M.M.; Castro, B.B.; Gonçalves, F.; Pereira, M.J.; Correia, A. Differential inter- and intra-specific responses of Aphanizomenon strains to nutrient limitation and algal growth inhibition. J. Plankton. Res. 2011, 33, 1606-1616. [CrossRef]

42. Sabour, B.; Loudiki, M.; Vasconcelos, V. Growth responses of Microcystis ichthyoblabe Kützing and Anabaena aphanizomenoides Forti (Cyanobacteria) under different nitrogen and phosphorus conditions. Chem. Ecol. 2009, 25, 337-344. [CrossRef]

43. Budzyńska, A.; Gołdyn, R. Domination of invasive Nostocales (Cyanoprokaryota) at $52^{\circ} \mathrm{N}$ latitude. Phycol. Res. 2017, 65, 322-332. [CrossRef]

44. Mehnert, G.; Leunert, F.; Cirés, S.; Jöhnk, K.D.; Rücker, J.; Nixdorf, B.; Wiedner, C. Competitiveness of invasive and native cyanobacteria from temperate freshwaters under various light and temperature conditions. J. Plankton Res. 2010, 32, 1009-1021. [CrossRef]

45. Van de Waal, D.B.; Smith, V.H.; Declerck, S.A.J.; Stam, E.C.M.; Elser, J.J. Stoichiometric regulation of phytoplankton toxins. Ecol. Lett. 2014, 17, 736-742. [CrossRef] [PubMed]

46. Kellmann, R.; Mihali, T.K.; Jeon, Y.J.; Pickford, R.; Pomati, F.; Neilan, B.A. Biosynthetic Intermediate Analysis and Functional Homology Reveal a Saxitoxin Gene Cluster in Cyanobacteria. Appl. Environ. Microbiol. 2008, 74, 4044-4053. [CrossRef] [PubMed]

47. Vargas, S.R.; Dos Santos, P.V.; Bottino, F.; Calijuri, M.d.C. Effect of nutrient concentration on growth and saxitoxin production of Raphidiopsis raciborskii (Cyanophyta) interacting with Monoraphidium contortum (Chlorophyceae). J. Appl. Phycol. 2020, 32, 421-430. [CrossRef]

48. Toporowska, M.; Mazur-Marzec, H.; Pawlik-Skowrońska, B. The Effects of Cyanobacterial Bloom Extracts on the Biomass, Chl-a, MC and Other Oligopeptides Contents in a Natural Planktothrix agardhii Population. Int. J. Environ. Res. Public Health 2020, 17, 2881. [CrossRef] [PubMed]

49. Welker, M.; Šejnohová, L.; Némethová, D.; Döhren, H.; Jarkovský, J.; Maršálek, B. Seasonal shifts in chemotype composition of Microcystis sp. Communities in the pelagial and the sediment of a shallow reservoir. Limnol. Oceanogr. 2007, 52, 609-619. [CrossRef] 
50. Orr, P.T.; Jones, G.J. Relationship between microcystin production and cell division rates in nitrogen-limited Microcystis aeruginosa cultures. Limnol. Oceanogr. 1998, 43, 1604-1614. [CrossRef]

51. Briand, J.F.; Jacquet, S.; Flinois, C.; Avois-Jacquet, C.; Maisonnette, C.; Leberre, B.; Humbert, J.-F. Variations in the microcystin production of Planktothrix rubescens (Cyanobacteria) assessed from a four-year survey of Lac du Bourget (France) and from laboratory experiments. Microb. Ecol. 2005, 50, 418-428. [CrossRef]

52. Kurmayer, R.; Deng, L.; Entfellner, E. Role of toxic and bioactive secondary metabolites in colonization and bloom formation by filamentous cyanobacteria Planktothrix. Harmful Algae 2016, 54, 69-86. [CrossRef]

53. Paerl, H.W.; Havens, K.E.; Hall, N.S.; Otten, T.G.; Zhu, M.; Xu, H.; Zhu, G.; Qin, B. Mitigating a global expansion of toxic cyanobacterial blooms: Confounding effects and challenges posed by climate change. Mar. Freshw. Res. 2019, 71, 579-592. [CrossRef]

54. Zhang, W.; Jeppesen, E.; Wang, M.; Xu, X.; Wang, L. Allelopathic effect boosts Chrysosporum ovalisporum dominance in summer at the expense of Microcystis panniformis in a shallow coastal water body. Environ. Sci. Pollut. Res. Int. 2017, 24, 4666-4675. [CrossRef] [PubMed]

55. Burford, M.A.; Carey, C.C.; Hamilton, D.P.; Huisman, J.; Paerl, H.W.; Wood, S.A.; Wulf, A. Perspective: Advancing the research agenda for improving understanding of cyanobacteria in a future of global change. Harmful Algae 2020, 91, 101601. [CrossRef] [PubMed]

56. Reynolds, C.S. Photosynthesis and Carbon Acquisition in Phytoplankton. In The Ecology of Phytoplankton; Reynolds, C., Ed.; Cambridge University Press: London, UK, 2006; pp. 93-143.

57. González-Madina, L.; Pacheco, J.P.; Yema, L.; de Tezanos, P.; Levrini, P.; Clemente, J.; Crisci, C.; Lagomarsino, J.J.; Méndez, G.; Fosalba, C.; et al. Drivers of cyanobacteria dominance, composition and nitrogen fixing behavior in a shallow lake with alternative regimes in time and space, Laguna del Sauce (Maldonado, Uruguay). Hydrobiologia 2019, 829, 61-76. [CrossRef]

58. Teubner, K.; Feyerabend, R.; Henning, M.; Nicklisch, A.; Woitke, P.; Kohl, J.-G. Alternative blooming of Aphanizomenon flos-aquae or Planktothrix agardhii induced by the timing of the critical nitrogen: Phosphorus ratio in hypertrophic riverine lakes. Arch. Hydrobiol. 1999, 54, 325-344.

59. Rzymski, P.; Poniedziałek, B.; Mankiewicz-Boczek, J.; Faassen, E.J.; Jurczak, T.; Gagała-Borowska, I.; Ballot, A.; Lürling, M.; Kokociński, M. Polyphasic toxicological screening of Cylindrospermopsis raciborskii and Aphanizomenon gracile isolated in Poland. Algal Res. 2017, 24, 72-80. [CrossRef]

60. Wejnerowski, Ł.; Falfushynska, H.; Horyn, O.; Osypenko, I.; Kokociński, M.; Meriluoto, J.; Jurczak, T.; Poniedziałek, B.; Pniewski, F.; Rzymski, P. In Vitro Toxicological Screening of Stable and Senescing Cultures of Aphanizomenon, Planktothrix, and Raphidiopsis Toxins 2020, 12, 400. [CrossRef] [PubMed]

61. Rzymski, P.; Poniedzialek, B. In Search of Environmental Role of Cylindrospermopsin: A Review on Global Distribution and Ecology of Its Producers. Water Res. 2014, 66, 320-337. [CrossRef]

62. Ma, Z.L.; Fang, T.X.; Thring, R.W.; Li, Y.; Yu, H.; Zhou, Q.; Zhao, M. Toxic and non-toxic strains of Microcystis aeruginosa induce temperature dependent allelopathy toward growth and photosynthesis of Chlorella vulgaris. Harmful Algae 2015, 48, 21-29. [CrossRef]

63. Briand, E.; Reubrecht, S.; Mondeguer, F.; Sibat, M.; Hess, P.; Amzil, Z.; Bormans, M. Chemically mediated interactions between Microcystis and Planktothrix: Impact on their growth, morphology and metabolic profiles. Environ. Microbiol. 2018, 21, 1552-1566. [CrossRef]

64. Komárek, J.; Anagnostidis, K. Cyanoprokaryota, part 2. Oscillatoriales. In Süsswasser Flora von Mitteleuropa Band 19/2; Büdel, B., Gärtner, G., Krienitz, L., Schagerl, M., Eds.; Gustav Fischer: Jena, Germany, 2005; pp. 1-759.

65. Komárek, J. Cyanoprokaryota. 3. Heterocytous genera. In Süswasserflora von Mitteleuropa/Freshwater Flora of Central Europe; Büdel, B., Gärtner, G., Krienitz, L., Schagerl, M., Eds.; Springer: Berlin, Germany, 2013; pp. 1-1130.

66. Torres, C.; Lürling, M.; Marinho, M.M. Assessment of the Effects of Light vailability on Growth and Competition between Strains of Planktothrix agardhii and Microcystis aeruginosa. Microb. Ecol. 2016, 71, 802-813. [CrossRef]

67. Wetzel, R.G. Limnology, 2nd ed.; Saunders College Publishing: Philadelphia, PA, USA, 1983.

68. Guillard, R.R.L. Division rates. In Handbook of Phycological Methods: Culture Methods and Growth Measurements; Stein, J.R., Ed.; Cambridge University Press: London, UK, 1973; pp. 289-311.

69. Khomutovska, N.; Sandzewicz, M.; Łach, Ł.; Suska-Malawska, M.; Chmielewska, M.; Mazur-Marzec, H.; Cegłowska, M.; Niyatbekov, T.; Wood, S.A.; Puddick, J.; et al. Limited Microcystin, Anatoxin and Cylindrospermopsin Production by Cyanobacteria from Microbial Mats in Cold Deserts. Toxins 2020, 12, 244. [CrossRef] [PubMed]

70. Starmach, K. Plankton Roślinny Wód Słodkich; PWN: Warszawa-Kraków, Poland, 1989; pp. 1-62.

71. Olrik, K.; Blomquist, P.; Brettum, P.; Cronberg, G.; Eloranta, P. Methods for Quantitative Assessment of Phytoplankton in Freshwaters, Part I; Naturvårdsverket förlag: Stockholm, Sweden, 1998; pp. 1-86.

72. Olenina, I.; Hajdu, S.; Edler, L.; Andersson, A.; Wasmund, N.; Busch, S.; Göbel, J.; Gromisz, S.; Huseby, S.; Huttunen, M.; et al. Biovolumes and Size-Classes of Phytoplankton in the Baltic Sea; Helsinki Commission Baltic Marine Environment Protection Commission: Helsinki, Finland, 2006; pp. 1-144. 